\title{
Quality of life after liver transplantation with old donor graft
}

\author{
Qualidade de vida pós-transplante hepático com enxerto de doador idoso
}

Maria José Nascimento Flor ${ }^{1}$, José Huygens Parente Garcia ${ }^{1}$, Maria Isis Freire de Aguiar², João Marcos de Meneses e Silva ${ }^{3}$, Paulo César de Almeida ${ }^{4}$, Francisca Diana da Silva Negreiros ${ }^{1}$

Objective: to compare the quality of life of liver transplant patients who received liver from donor aged $\leq 60$ or $>60$ years old. Methods: a prospective study with a sample of 141 recipients from liver donors aged equal to or less than 60 years and recipients of elderly donor liver, in a reference center. Authors used a tool for identification and the Short Form-36. The Student-t and Mann-Whitney tests were applied for comparison between groups. Results: there were higher levels of quality of life with a statistically significant difference: Group A in social aspect $(\mathrm{p}=0.02)$ and Group $\mathrm{B}>50$ months of transplantation $(\mathrm{p}=0.05)$ in physical component summary. Conclusion: the quality of life of liver receptors from older donor livers was similar to those who received a graft from younger donors in most dimensions. Transplanting time had a positive impact on the quality of life of elderly recipients.

Descriptors: Quality of Life; Liver Transplantation; Donor Selection; Nursing.

Objetivo: comparar a qualidade de vida dos pacientes transplantados hepáticos que receberam fígado de doador com idade $\leq 60$ ou > 60 anos. Métodos: estudo prospectivo, com amostra de 141 receptores de fígado de doador com idade igual ou menor de 60 anos e receptores de fígado de doador idoso, em um centro de referência. Utilizou-se instrumento para identificação e o questionário Short Form-36. Foram aplicados os testes $t$-Student e Mann-Whitney para comparação entre grupos. Resultados: identificaram-se maiores níveis de qualidade de vida com diferenças estatisticamente significativas: Grupo A no aspecto social $(p=0,02)$ e o Grupo B com $>50$ meses de transplante $(\mathrm{p}=0,05)$ no componente sumarizado físico. Conclusão: a qualidade de vida de receptores de fígado de doador idoso foi semelhante aos que receberam enxerto de doadores mais jovens na maioria das dimensões. 0 tempo de transplante teve impacto positivo na qualidade de vida de receptores idosos.

Descritores: Qualidade de Vida; Transplante de Fígado; Seleção do Doador; Enfermagem.

\footnotetext{
${ }^{1}$ Hospital Universitário Walter Cantídio, Universidade Federal do Ceará. Fortaleza, CE, Brazil.

${ }^{2}$ Universidade Federal do Ceará. Fortaleza, CE, Brazil.

${ }^{3}$ Centro de Hematologia e Hemoterapia do Ceará. Fortaleza, CE, Brazil.

${ }^{4}$ Universidade Estadual do Ceará. Fortaleza, CE, Brazil.

Corresponding author: Maria José Nascimento Flor

Rua Henrique Rabelo, 1050 - Joaquim Távora. CEP 60.110-540. Fortaleza, CE, Brazil. E-mail: mzflor@hotmail.com
} 


\section{Introduction}

The progress achieved in Medicine with new interventions for the treatment of liver diseases, especially in irreversible liver failure, has provided increased survival with quality. Liver transplantation is unquestionably the therapy of choice since both survival and quality of life are superior in transplant patients compared to similar patients without transplantation $^{(1)}$.

The demand of people who need liver transplantation in increasingly severe and complex situations has increased in large proportions, surpassing organ donations. Researchers say there is no shortage of potential donors, but potential donors do not become effective by the lack of notification to the Transplant Centers or by family denial. Other factors such as the lack of training of teams, improper maintenance of the donor and equipment to prove brain death also prevent to occurring the donation process $^{(2)}$.

The annual growth of liver transplantation from 2008 to 2014 was $1.9 \%$, of which $1.1 \%$ was with deceased donor and $10.3 \%$ with living donor. In the first quarter of 2014, of 76.7 potential organ donors per million of population (pmp), only $14.2 \mathrm{pmp}$ became effective donors ${ }^{(3)}$.

The lack of ideal donors and the long waiting list have awakened in transplantation teams the need to use the borderline donor as a strategy to increase the number of transplants ${ }^{(3)}$. These donors, in various services, have provided decrease between receptors demand and organs offered, paying attention to a more careful assessment of these grafts ${ }^{(4)}$.

The borderline donor or expanded criteria donor, theoretically, is the one whose body has an increased risk of poor or absent initial function. Among the risk factors are being over 60 years old, steatosis greater than $30.0 \%$, cold ischemia longer than 13 hours and warm ischemia longer than fifty minutes, sodium above $155 \mathrm{mEq} / \mathrm{l}$, more than 3 days admitted to the Intensive Care Unit, prolonged hypotension, high doses of vasoactive drugs, stopped heart, among others ${ }^{(5)}$.

The increase in donations of elderly people decreases the waiting list and, at the same time, increases the strictness in the evaluation of the graft, since elderly people's livers show changes such as decreased weight, volume and reduced flow, without causing damage function. As for post-transplant complications with use of donors over 60 years old, there are controversies. Some scholars defend the thesis that these grafts are related to higher number of rejections, to biliary and vascular complications due to arteriosclerosis of the hepatic artery and to the transmission of occult tumors ${ }^{(5)}$.

The multidisciplinary team of Walter Cantídio University Hospital, at Federal University of Ceará, has performed liver transplant for more than a decade and has been particularly concerned with the quality of life of liver transplant recipients and with the introduction of new routines in their lives.

Evaluation of Health-Related Quality of Life has become an increasingly important measure in health care, especially in the field of chronic diseases, considering the patient's perception of the effects of the disease and treatments, and the impact on their daily life ${ }^{(6)}$.

In Brazil, translated and validated instruments have been applied in various groups of patients to assess the impact of various diseases and interventions in the lives of individuals. In this study, authors used the generic instrument Short Form - 36 (SF-36) by the possibility to assess health-related quality of life in positive (well-being) and negative aspects (illness or disease).

The nurse's role in liver transplantation begins in the outpatient service, when the customer is directed to evaluate the indication of transplantation. In this period, the nurse has the opportunity to guide the client and their family as the pre-transplant testing protocol; procedures before, during and after surgery; importance of adherence to treatment with immunosuppressants; and legal, ethical and technical 
criteria of the waiting list. When there is a potential donor, it is the nurse's responsibility to call in the receiver to hospitalization; mobilize the retrieval nursing staff and the lab technician; inform the nursing staff of the hospital unit, the operating room and recovery room ${ }^{(7)}$.

In the outpatient monitoring of pre-transplant patients, it was noticed an uneasiness regarding the advanced age of donors and impact on post-transplant outcomes, from which the following question emerged: can the advanced age of donors interfere with quality of life of liver transplant?

Thus, this study was aimed to compare the quality of life of liver transplant patients who received liver from donors aged $\leq 60$ or $>60$ years.

\section{Methods}

This is a prospective, descriptive and analytical study, conducted at the Liver Transplant Outpatient Clinic of Walter Cantídio University Hospital of the Federal University of Ceará, considered a national reference center.

The population consisted of patients undergoing liver transplant and the sample was determined by applying the inclusion criteria: patient transplanted and being monitored in the hospital, at least six months of transplantation, in physical and psychological conditions favorable to fill the instrument data collection, being literate; and exclusion criteria: incomplete data, transplant for fulminant hepatitis or double (kidney and liver), retransplantation, recipient being equal to or younger than eighteen years at the time of data collection.

The sample consisted of 141 patients divided into two groups: Group A ( $\mathrm{n}=100$ - recipients who received liver graft from donors aged less than or equal to sixty years) and Group B ( $\mathrm{n}=41$ - recipients who received liver graft from donors older than sixty years).

Data collection was conducted from March 2012 to July 2014 in the liver transplant outpatient clinic. Patients were invited to participate in the study when returning to post-transplant consultations and directed to a health care office, ensuring their privacy. Most questionnaires (139) were applied by the researcher, as an interview, and only two were selfadministered.

Authors used a questionnaire to collect recipients' identification data: age, gender, diagnosis of liver disease, value of the Model for End-Stage Liver Disease (MELD) on the day of transplantation and transplant time. The donors' data were obtained from the retrieval surgery report, including sex, age and diagnosis of disease.

To evaluate the quality of life of recipients, the Short Form 36 (SF-36) was applied, which is a multidimensional questionnaire consisting of 36 items, adapted and validated for the Brazilian population, including 8 scales or domains: 1-functional capacity (10 items), 2-limitation due to physical health (4 items), 3-pain (2 items), 4-general health status (5 items), 5-vitality (4 items), 6-social aspects (2 items) 7-limitation due to emotional problems (3 items), 8 -mental health ( 5 items), and one more question to compare the current health status and that of one year ago. The final score ranges from 0 to 100 , where zero corresponds to the worst general health status and 100 to the best health status ${ }^{(8)}$.

The eight domains were grouped forming two components representing the physical and mental health. The Physical Health Component comprises domains 1, 2, 3 and 4 and the Mental Health Component comprises the domains $5,6,7$ and $8^{(9)}$.

Data were recorded in a Microsoft $®$ Office 2008 Excel spreadsheet and processed using the Statistical Package for the Social Sciences version 22.0.

Descriptive statistical analysis was used, with categorical variables represented by absolute (n) and relative frequency (\%) and the scores of the SF36 domains were expressed as mean and standard deviation. Authors used the Student-t test to assess the difference between groups A and B according to the domains of the SF-36 and the variables MELD ( $\leq 20$ 
and $>20$ ) and transplant time. Then, it was used the nonparametric Mann-Whitney test to compare the groups according to recipients' age range. Values of $\mathrm{p}$ $\leq 0.05$ were considered statistically significant.

The study complied with the formal requirements contained in the national and international standards of regulatory research involving human subjects.

\section{Results}

The study included 141 patients who had undergone transplantation, of which 140 had received liver graft from donor with brain death and one received liver graft from a living donor.

The sociodemographic and clinical characteristics of the groups A and B are presented in Table 1.

Table 1 - Distribution of patients who has undergone liver transplantation according to clinical and sociodemographic profile $(n=141)$

\begin{tabular}{|c|c|c|c|c|c|c|}
\hline \multirow{2}{*}{ Characteristics } & \multicolumn{3}{|c|}{ Group A $(n=100)$} & \multicolumn{3}{|c|}{ Group B $(n=41)$} \\
\hline & Mean & \pm SD & n (\%) & Mean & $\pm \mathrm{SD}$ & n (\%) \\
\hline \multicolumn{7}{|l|}{ Gender } \\
\hline Male & & & $71(71.0)$ & & & $31(75,7)$ \\
\hline Female & & & $29(29.0)$ & & & $10(24,3)$ \\
\hline Age (in years) & 52,5 & $\pm 12,4$ & & 54 & $\pm 13,1$ & \\
\hline Transplantation time (months) & 34 & $\pm 19,8$ & & 36 & $\pm 21,7$ & \\
\hline MELD & 20 & $\pm 3,3$ & & 20 & $\pm 4,9$ & \\
\hline \multicolumn{7}{|l|}{ Liver disease } \\
\hline $\begin{array}{l}\text { Cirrhosis by viral hepatitis B, } \\
\text { C, D or associated }\end{array}$ & & & $27(27.0)$ & & & $9(22.0)$ \\
\hline Alcoholic cirrhosis & & & $16(16.0)$ & & & $8(19.0)$ \\
\hline $\begin{array}{l}\text { Viral Hepatitis/Carcinoma } \\
\text { Hepatocellular }\end{array}$ & & & $16(16.0)$ & & & $7(17.0)$ \\
\hline Cryptogenic cirrhosis & & & $10(10.0)$ & & & $6(14,7)$ \\
\hline Metabolic disease & & & $7(7.0)$ & & & $1(2,4)$ \\
\hline Viral/ Alcoholic Hepatitis & & & $6(6.0)$ & & & $4(9,8)$ \\
\hline Others & & & $18(18.0)$ & & & $6(14,6)$ \\
\hline
\end{tabular}

Among the Group A recipients, males prevailed (71.0\%), with mean age of 52.5 years old and transplantation time around 34 months. The etiology of higher frequency was viral hepatitis (B, C, D) alone or associated (27.0\%), followed by viral hepatitis/ hepatocellular carcinoma and alcoholic cirrhosis with $16.0 \%$ each. The criterion of disease severity used was MELD, with average value of 20 .

Among the Group B recipients, most were male $(75.7 \%)$ with mean age of 54 years old and an average transplant time of 36 months. The most frequent etiology was viral hepatitis (B, C, D) isolated or associated (22.0\%), followed by $19.0 \%$ alcoholic cirrhosis. The criterion of disease severity used was MELD, with average value of 20 (Table 1).

The results of the quality of life domains are shown in Table 2.

Table 2 - Comparative analysis between the groups A and $B$ recipients in relation to the domains of Physical Health Component and Mental Health Component of the SF-36 $(n=141)$

\begin{tabular}{|c|c|c|c|c|c|}
\hline \multirow[t]{2}{*}{ Domains } & \multicolumn{2}{|c|}{$\begin{array}{l}\text { Group A } \\
(n=100)\end{array}$} & \multicolumn{2}{|c|}{$\begin{array}{c}\text { Group B } \\
(n=41)\end{array}$} & \multirow[t]{2}{*}{ p } \\
\hline & Mean & \pm SD & Mean & $\pm \mathrm{SD}$ & \\
\hline \multicolumn{6}{|l|}{ Physical health component } \\
\hline Functional capacity & 88.5 & \pm 16.7 & 81.6 & \pm 21.0 & 0.061 \\
\hline Limitation due to physical health & 60.2 & \pm 40.8 & 53.0 & \pm 44.4 & 0.328 \\
\hline Pain & 86.8 & \pm 16.8 & 84.6 & \pm 16.8 & 0.469 \\
\hline General health status & 86.7 & \pm 12.9 & 80.8 & \pm 17.9 & 0.061 \\
\hline \multicolumn{6}{|l|}{ Mental health component } \\
\hline Vitality & 83.9 & \pm 16.3 & 77.1 & \pm 17.7 & 0.032 \\
\hline Social aspects & 92.5 & \pm 15.8 & 83.0 & \pm 24.6 & 0.026 \\
\hline Limitation due to emotional problems & 78.1 & \pm 35.5 & 70.8 & \pm 41.3 & 0.294 \\
\hline Mental health & 87.9 & \pm 11.3 & 81.5 & \pm 20.0 & 0.061 \\
\hline
\end{tabular}

According to the results, the liver transplant recipients in Group A had higher average of quality of life in the domains Social Aspects (92.5) and Functional Capacity (88.5), whereas liver transplant recipients in Group B had higher average of quality life in the domains Pain (84.6) and Social Aspects (83.0).

Statistically significant differences between averages were only observed in domains Social Aspects ( $p=0.026)$ and Vitality $(p=0.032)$, with greater scores of quality of life for Group A. On the other hand, there was no statistically significant difference between the average quality of life of the 
remaining domains between groups.

There was still highlight for the average of the domain Limitation due to Physical Health (53.04) to be the lowest among all domains of the SF-36.
The variables MELD, age group of the recipient and transplant time were compared between groups A and B in Mental Component Summary and Physical Component Summary, as shown in Table 3.

Table 3 - Comparative analysis between the means of Mental Component Summary and Physical Component Summary of groups A and B, according to the variables MELD, age group and time of receiving the transplant $(\mathrm{n}=141)$

\begin{tabular}{|c|c|c|c|c|c|c|c|c|c|c|}
\hline \multirow{3}{*}{ Variable } & \multicolumn{5}{|c|}{ Mental Component Summary } & \multicolumn{5}{|c|}{ Physical Component Summary } \\
\hline & \multicolumn{2}{|c|}{ Group A } & \multicolumn{2}{|c|}{ Group B } & \multirow{2}{*}{$\mathbf{p}$} & \multicolumn{2}{|c|}{ Group A } & \multicolumn{2}{|c|}{ Group B } & \multirow{2}{*}{$\mathbf{p}$} \\
\hline & Mean & \pm SD & Mean & \pm SD & & Mean & \pm SD & Mean & \pm SD & \\
\hline \multicolumn{11}{|l|}{ MELD } \\
\hline$\leq 20$ & 85.4 & 14.0 & 81.3 & 19.1 & \multirow{2}{*}{$\begin{array}{l}0.274 \\
0.127\end{array}$} & 72.9 & 12.6 & 74.8 & 17.4 & \multirow{2}{*}{$\begin{array}{l}0.574 \\
0.364\end{array}$} \\
\hline$>20$ & 80.5 & 18.6 & 88.0 & 3.3 & & 69.4 & 12.1 & 72.8 & 12.2 & \\
\hline \multicolumn{11}{|c|}{ Age group (in years) } \\
\hline $19-40$ & 79.6 & 19.8 & 85.3 & 10.3 & \multirow{3}{*}{$\begin{array}{l}0.433 \\
0.718 \\
0.215\end{array}$} & 66.8 & 13.9 & 72.8 & 10,9 & \multirow{3}{*}{$\begin{array}{l}0.166 \\
0.450\end{array}$} \\
\hline $41-59$ & 81.9 & 16.9 & 83.5 & 15.8 & & 71.0 & 12.0 & 77.0 & 16,9 & \\
\hline$\geq 60$ & 88.3 & 11.2 & 83.3 & 17.9 & & 75.3 & 11.6 & 71.9 & 16,6 & \\
\hline \multicolumn{11}{|c|}{ Transplantation time (in months ) } \\
\hline $6-30$ & 79.9 & 18.8 & 84.1 & 13.3 & \multirow{3}{*}{$\begin{array}{l}0.413 \\
0.548 \\
0.874\end{array}$} & 68.9 & 14.1 & 70.3 & 16.7 & \multirow{3}{*}{$\begin{array}{l}0.755 \\
0.681 \\
0.005\end{array}$} \\
\hline $31-50$ & 85.1 & 12.2 & 81.9 & 21.0 & & 75.7 & 12.8 & 73.7 & 17.5 & \\
\hline$>50$ & 85.9 & 15.8 & 85.0 & 13.2 & & 70.6 & 8.6 & 79.9 & 10.7 & \\
\hline
\end{tabular}

According to data from the Mental Component Summary, Group A patients had higher average quality of life (85.4) compared to Group B (81.3) in patients with MELD values lower than or equal to $20(\mathrm{p}=0.274)$, but had lower scores of quality of life (80.5) among patients with MELD values greater than 20 (0.127), although no significant differences were identified in the Student-t test.

Regarding the Physical Component Summary, the average of Group B were higher than group A, regardless of MELD values, with higher average of quality of life for MELD values lower than or equal to 20 (74.8), with no significant differences between groups.

Groups A and B showed higher average of quality of life in Mental Component Summary in all age groups. There is highlight to the average of Group A (88.3), in the age group equal to or older than 60 years, although there was no statistically significant difference when compared to Group B ( $p=0.215)$, according to the Mann-Whitney test.
In the Physical Component Summary, the average of Group B (77.0) in the age group of 41-59 years stood out, although with no statistically significant difference ( $p=0.166)$ when compared to Group A.

In the age group 19-40 years there was also no statistically significant difference between the average quality of life of Groups A and B in Mental Component Summary $(p=0.433)$ and Physical Component Summary $(p=0.278)$.

As for the transplantation time, groups $\mathrm{A}$ and B showed higher average values of quality of life in Mental Component Summary, with highlight to the Group (85.9) and Group B (85.0) in patients over 50 months of transplantation, with no significant difference between them according to the Student- $t$ test.

On the other hand, patients in Group B over 50 months of transplantation had higher scores in quality of life related to Physical Component Summary (79.9), with statistically significant difference $(p=0.005)$ compared to Group A. 


\section{Discussion}

The use of the SF-36 enabled the evaluation of the quality of life of liver transplant recipients and comparison between groups of different ages, including physical, social and emotional aspects. However, although it is a multidimensional instrument, it does not measure specificities related to liver disease and transplant recipient condition, being considered a limitation of this study.

The results contribute to aggregate knowledge to the indication of use of graft with expanded criteria, especially regarding the age of the donor, providing resources for the transplant centers in the decision by the transplant, which may favor the reduction of people on the waiting list and their morbidity and mortality, thus providing the opportunity of health recovery and quality of life for transplant candidates.

In the sample with 141 liver donors, about one third of donors were older than sixty years old. In the State of Ceará, in 2014, 29.0\% of donors were aged between 50 and 64 years $^{(3)}$.

A study conducted in Spain, with 149 recipients of a transplant center, noted that the survival of liver graft from donors aged 60 years or older was $71.4 \%$ after a year of transplant, and there were no significant differences when compared to the group aged less than sixty years ${ }^{(4)}$. The survival benefit of patients receiving old donor liver has also been confirmed in other studies ${ }^{(10-11)}$.

In assessing the quality of life of liver transplant patients, based on the SF-36, domains that showed better quality of life in Group A were: social aspect and functional capacity; whereas in Group B these were pain and social aspect.

In follow-up to 299 adult patients undergoing liver transplantation, of which 171 responded to the SF-36, the domain evaluated with highest score was related to social aspects and those with lowest score were physical ability and vitality ${ }^{(12)}$.

Even after transplantation, people still undergo changes in various fields, because of the need to adapt to a new life, medical routine, continuous use of immunosuppressive therapy and risk of complications. Moreover, the way they perceive the social support given to them may have an impact on their quality of life ${ }^{(9)}$.

A study of 82 liver transplant patients followed for six months noted that pre-transplant anxiety was predictive of post-transplant anxiety and indicated tendency to depression, also interfering with quality of life in various domains, including pain in the bodily pain, functional limitations due to emotional problems and mental health ${ }^{(13)}$.

Regarding the severity of liver disease, in the study conducted, recipients from donors aged more than 60 years with MELD $>20$ had better quality of life, however, the MELD value had no significant difference in results.

Currently, the MELD is the resource used to prioritize patients on the waiting list for liver transplantation. Research review conducted in three databases on this model of organ allocation with 30 items showed that the MELD score has significantly increased the short-term survival rate of the most serious patients of the waiting list for liver transplant, but had no significant impact on the survival rate of less serious patients ${ }^{(14)}$.

Study in liver transplant patients clearly showed that the MELD $\geq 20$ is a risk predictor of mortality after liver transplantation, within 90 days to a year. The ability to identify high-risk patients after liver transplantation is a valuable tool that can lead to deciding for more effective post-operative therapies. Also, it may be useful to include success rates in the expected postoperative in strategies for organ allocation $^{(15)}$.

Looking at the quality of life of liver transplant by age, it showed that despite the improvement in the quality of life in the Mental Component Summary of both groups, there was no significant difference between them.

Researchers investigated the quality of life of 256 adults undergoing liver transplantation, of 
which 15 (5.9\%) developed anxiety and four (1.6\%) had severe post-transplant depression, and found that age $>45$ years at the time of transplantation, the absence of complications, anxiety and depression and deceased donor graft were possible factors influencing the Health-Related Quality of Life in the postoperative period of liver transplant recipients ${ }^{(16)}$.

The average age of patients with liver disease who require transplantation has increased, as well as the concern for the survival and quality of life after transplantation. A retrospective study of 8,070 liver transplant patients aged 60 years or older during eleven years noted that post-transplant survival was $83.0 \%$ in the first year and $67.0 \%$ in the fifth year. It concluded that it is possible to optimize donor selection to benefit the recipients aged over sixty years, through the Older Recipient Prognostic Score system $^{(17) .}$

The age of recipient was one of the factors that contributed to the increased mortality rate in the study, after two years of transplantation, increasing from 1 to $4.0 \%$ per year, as a result of cardiovascular, respiratory, neurological complications and emergence of new cancer ${ }^{(18)}$.

In this research, it was found that the patients who received liver from donors $>60$ years of age showed a better quality of life after over 50 months of transplantation. Consistent with these findings, a researcher evaluated liver transplant patients and observed a sample of 33 subjects (18 with six months of transplantation and 15 with twelve months) that improvement in the quality of life after 12 months of transplantation is very perceptive, and was less expressive in the group with six months of transplantation. The improvement was most evident in physical symptoms than in the psychosocial dimension ${ }^{(19)}$.

Twenty-three studies with 5,402 patients have showed that the quality of life after liver transplantation remains higher than the preoperative status up to 20 years after surgery, but postoperative complications may predict worse quality of life scores, especially in physical domains. The authors have found that in the functional domains patients remain with independence in self-care and mobility in long term. Employment rates have recovered in the short term, but declined after five years, and differ significantly between different etiologies of liver disease. The overall quality of life improves to a level similar to the general population, but the physical function continues to be worse. Participation in postoperative physical activity is associated with better results of quality of life in liver transplant recipients compared with the general population ${ }^{(20)}$.

Despite the favorable results, further studies are important to the safe use and/or indication of liver graft with advanced age donor, since the literature is scarce on this theme. The experience of other centers reporting their results is important to assist in decision making from other teams and the patients themselves.

\section{Conclusion}

The study found that the quality of life of older donor liver recipients was similar to those who received grafts from younger donors in most dimensions, bringing advances in understanding the implications of using older donor graft, which may contribute with new studies for a more reliable indication.

\section{Collaborations}

Flor MJN contributed to the project design, analysis, data interpretation, article writing and final approval of the version to be published. Garcia JHP, Aguiar MIF, Silva JMM, Almeida PC and Negreiros FDS contributed to the relevant critical review of the intellectual content, article writing and final approval of the version to be published. 


\section{References}

1. Saidi RF. Current status of liver transplantation. Arch Iran Med. 2012; 15(12):772-6.

2. Garcia CD. Manual de doações e transplantes. Rio de Janeiro: Elsevier; 2013.

3. Associação Brasileira de Transplante de Órgãos. Dimensionamento dos transplantes no Brasil e em cada estado (2007-2014). Registro Brasileiro de Transplantes [Internet]. 2014 [citado $2015 \mathrm{dec}$ 13]; XX(4):3-10. Disponível em: http://www.abto. org.br/abtov03/upload/file/rbt/2014/rbt2014lib.pdf

4. Serrano MT, Garcia-Gil A, Arenas J, Ber Y, Cortes L, Valiente C, et al. Outcome of liver transplantation using donors older than 60 years of age. Clin Transplant. 2010; 24(4):543-9.

5. Fonseca Neto OCL. O doador limítrofe no transplante hepático. Brasília Med. 2011; 48(1):65-9.

6. Nicolussi AC, Sawada NO, Cardozo FMC, Andrade A, Paula JM. Health-related quality of life of cancer patients undergoing chemotherapy. Rev Rene. 2014; 15(1):132-40.

7. Pereira WA. Manual de transplantes de órgãos e tecidos. Belo Horizonte: Coopmed; 2012.

8. Ciconelli RM, Ferraz MB, Santos W, Meinão I, Quaresma MR. Tradução para a língua portuguesa e validação do questionário genérico de avaliação de qualidade de vida SF-36 (Brasil SF-36). Rev Bras Reumatol. 1999; 39(3):143-50.

9. Abrunheiro LMM. A satisfação com o suporte social e a qualidade de vida no doente após transplante hepático [Internet]. [citado 2015 set 10]. Disponível em: http://www.psicologia.pt/ artigos/textos/A0255.pdf

10. Jiménez-Romero $C$, Clemares-Lama M, ManriqueMunicio A, Garcia-Sesma A, Calvo-Pulido J, Moreno-Gonzále E. Long-term results using old liver grafts for transplantation sexagenerian versus liver donors older than 70 years. World J Surg. 2013; 37(9):2211-21.

11. Rauchfuss F, Voigt R, Dittmar Y, Heise M, Settmacher U. Liver transplantation utilizing old donor organs: a German single-center experience. Transplant Proc. 2010; 42(1):175-7.
12. Volk ML, Hagan M. Organ quality and quality of life after liver transplantation. Liver Int. 2011; 17(12):1443-7.

13. Miller LR, Paulson D, Eshelman A, Bugns M, Broun KA, Moonka D, et al. Mental health affects the quality of life and recovery liver transplantation . Liver Transplant. 2013; 19(11):1272-8.

14. Chaib E, Figueira ERR, Brunheroto A, Gatti AP, Fernandes DV, D’Albuquerque LAC. A seleção de pacientes utilizando-se o critério MELD melhora a sobrevida a curto prazo dos pacientes submetidos ao transplante de fígado? Arq Bras Cir Dig. 2013; 26(4):324-7.

15. Bruns H, Lozanovski VJ, Schultze D, Hillebrand N, Hinz U, Büchler MW, et al. Prediction of postoperative mortality in liver transplantation in the era of MELD-based liver allocation: a multivariate analysis. PLoS One. 2014; 9(6):e98782.

16. Chen PX, Yan LN, Wang WT. Health-related quality of life of 256 recipients after liver transplantation World J Gastroenterol. 2012; 18(36):5114-21.

17. Aloia TA, Knight R, Gaber AO, Ghobrial RM, Gosssi JA. Analysis of liver transplant outcomes for united network for organ sharing recipients 60 years old or older identifies multiple model for end-stage liver disease-independent prognostic factors. Liver Transplant. 2010; 16(8):950-9.

18. Zahn A, Seubert L, Jünger J, Schellberg D, Weiss $\mathrm{KH}$, Schemmer P, et al. Factors influencing longterm quality of life and depression in German liver transplant recipients: a single-center crosssectional study. Ann Transplant. 2013; 18:327-35.

19. Matos MMPC. Impacto da doença e do transplante hepático na qualidade de vida de doentes com cirrose: estudo exploratório. Cad Saúde Pública. 2011; 4(1):7-36.

20. Yang LS, Sham LL, Saxeno A, Mornis DL. Liver transplantation: a systematic review of long-term quality of life. Liver Int. 2014; 34(9):1298-313. 